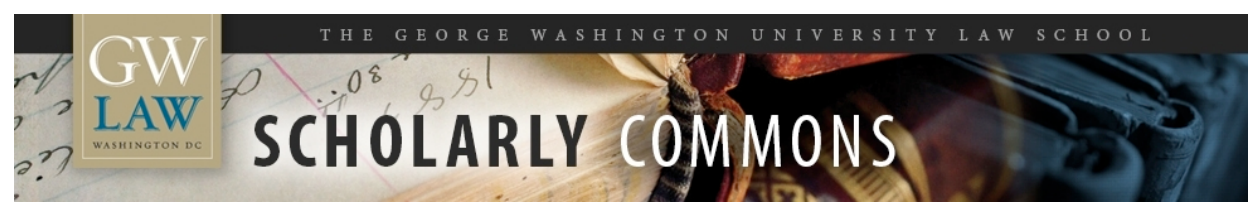

GW Law Faculty Publications \& Other Works

Faculty Scholarship

2018

\title{
$\S 6.11$ Juror Testimony and Affidavits Barred
}

Christopher B. Mueller

University of Colorado Law School

Laird Kirkpatrick

George Washington University Law School, lkirkpatrick@law.gwu.edu

Liesa Richter

University of Oklahoma College of Law

Follow this and additional works at: https://scholarship.law.gwu.edu/faculty_publications

Part of the Law Commons

\section{Recommended Citation}

Mueller, Christopher B. and Kirkpatrick, Laird C. and Richter, Liesa, §6.11 Juror Testimony and Affidavits Barred (2018). C. Mueller, L. Kirkpatrick, \& L. Richter, Evidence §6.11 (6th ed. Wolters Kluwer 2018); GWU Law School Public Law Research Paper No. 2018-69; GWU Legal Studies Research Paper No. 2018-69. Available at SSRN: https://ssrn.com/abstract $=3277060$

This Chapter is brought to you for free and open access by the Faculty Scholarship at Scholarly Commons. It has been accepted for inclusion in GW Law Faculty Publications \& Other Works by an authorized administrator of Scholarly Commons. For more information, please contact spagel@law.gwu.edu. 


\section{\$6.11 Juror Testimony and Affidavits Barred}

FRE 606(b) bars juror testimony or statements to prove any incident occurring or statement made during deliberations unless it fits either of three express and as many as three other unstated exceptions that are discussed in ensuing sections. It bars such testimony or statements to prove the effect of anything on the mind or emotions of a juror or to prove the mental processes of any juror. Obviously these categories overlap: A juror could hardly describe his mental processes without revealing the effect of something on his mind or emotions, and proof of a statement during deliberations would inevitably tell something about mental processes or the effect of something on the mind or emotions of jurors. The important point is that it would be hard to paint with a broader brush, and the Rule reaches everything relating to deliberations unless an exception applies.

\section{Evidence or reasons}

So often do unhappy litigants attack verdicts by juror testimony or statements (typically proved by affidavit) that many decided cases provide authoritative guidance, and the cases fall into patterns that are easy to describe. In what follows, it should be assumed that the evidence is offered in an attempt to set aside a verdict. To begin at an obvious point, the exclusionary principle bars use of juror testimony or statements as proof of the evidence that counted most or the reasons behind the verdict ${ }^{1}$ or to show that certain instructions counted or would have counted if they had been given. ${ }^{2}$

\section{Errors, misunderstandings}

The exclusionary principle applies to juror testimony or statements describing even serious errors or misunderstandings on points of law or the proper basis of decision. Thus FRE 606(b) bars such testimony or statements indicating that one or more jurors ignored or misunderstood

§6.11 1. Rushen v. Spain, 464 U.S. 114 (1983) (cannot generally testify about “mental processes by which” verdict was reached); United States v. Maree, 934 F.2d 196, 201 (9th Cir. 1991) (affidavit inadmissible insofar as it said friends with whom juror discussed case influenced her vote for conviction).

2. Capps v. Sullivan, 921 F.2d 260, 263 (10th Cir. 1990) (affidavits saying jurors would have voted to acquit if given entrapment instruction). 
instructions ${ }^{3}$ or interrogatories, ${ }^{4}$ or ignored or misunderstood applicable legal principles ${ }^{5}$ or the requirement of a unanimous decision, ${ }^{6}$ or misused evidence. ${ }^{7}$ The Rule also bars proof that one or more jurors improperly speculated on extrarecord matters, ${ }^{8}$ such as the impact of insurance on a judgment or the impact of a judgment on insurance rates, ${ }^{9}$ or the impact of contingent fees ${ }^{10}$ or taxes. ${ }^{11}$ The Rule also bars proof that one or more jurors held it against the accused that he failed to take the stand, ${ }^{12}$ or speculated that the court would be lenient or that defendant would be released on probation or quickly paroled, ${ }^{13}$ or even that an insane defendant should be found guilty or would be released to commit more crimes, ${ }^{14}$ or that jurors took into account the presence or absence of

3. Young v. Davis, 835 F.3d 520, 529 (5th Cir. 2016) (can’t show that jurors were “misled by faulty instructions”); Marsingill v. O’Malley, 58 P.3d 495, 505 n.27 (Alaska 2002) (jurors misunderstood instructions); United States v. Febus, 218 F.3d 784, 794 (7th Cir. 2000) (instructions confused juror).

4. Robles v. Exxon Corp., 862 F.2d 1201, 1206-1209 (5th Cir. 1989) (some jurors thought interrogatories meant court would award damages if plaintiff was more than 51 percent at fault), cert. denied, 490 U.S. 1051.

5. Peveto v. Sears, Roebuck \& Co., 807 F.2d 486, 488-489 (5th Cir. 1987) (“always some danger that jurors will misunderstand the law or consider improper factors").

6. United States v. Homer, 411 F. Supp. 972, 978 (W.D. Pa. 1976) (not hearing instruction that verdict had to be unanimous), aff'd, 545 F.2d 864 (3d Cir. 1976), cert. denied, 431 U.S. 954.

7. United States v. Stewart, 433 F.3d 273, 307-308 (2d Cir. 2006) (cannot show that jurors considered as proof against one defendant evidence they were instructed to consider only against another).

8. Morgan v. Woessner, 975 F.2d 629 (9th Cir. 1992) (jurors "wanted to send a message to City” on police misconduct); Dobbs v. Zant, 963 F.2d 1403, 1411 (11th Cir. 1991) (jury thought defendant would not be executed because Supreme Court had forbidden executions).

9. See Holden v. Porter, 405 F.2d 878, 879 (10th Cir. 1969); Farmers Co-operative Elevator Assoc. v. Strand, 382 F.2d 224, 230 (8th Cir. 1967), cert. denied, 389 U.S. 1014.

10. Gault v. Poor Sisters of St. Frances, 375 F.2d 539, 548-550 (6th Cir. 1967) (discussing amount of recovery that would go to plaintiff's attorney).

11. Id. at 548-551 (6th Cir. 1967) (discussing income tax plaintiff might pay out of recovery).

12. United States v. Rutherford, 371 F.3d 634, 640 (9th Cir. 2004) (cannot prove that jury discussed failure of one codefendant to testify).

13. United States v. Gonzales, 227 F.3d 520, 526-527 (6th Cir. 2000) (statements that defendant would only get slap on wrist if convicted because he was charged with white collar crime).

14. Fulghum v. Ford, 850 F.2d 1529, 1535 (11th Cir. 1988) (jurors thought defendant was insane but feared that not 
other co-offenders in deciding defendant's guilt. ${ }^{15}$

\section{Prejudice}

Usually the Rule bars proof of prejudicial attitudes toward the parties or the kinds of positions being taken in suit, ${ }^{16}$ as well as proof of inappropriate or scornful or mocking comments about parties, lawyers, evidence, or theories presented. ${ }^{17}$

\section{Using alcohol, drugs}

Somewhat surprisingly, the Rule also bars proof by juror testimony or affidavit that jurors consumed alcohol and indulged in substance abuse during trial. In 1987 this question reached the Supreme Court in Tanner v. United States, where the evidence suggested that several jurors fell asleep during proceedings and were adversely affected in their reasoning abilities. Tanner concluded that allegations of alcohol and substance abuse during trial do not raise provable issues of "outside influence," and do not show that the jury was incompetent, accepting for the sake of argument that such a showing may be made. ${ }^{18}$ One surprising point about Tanner is its implicit holding that the Rule governs proof of predeliberative jury misconduct, ${ }^{19}$ but perhaps its greatest significance is in construing the term “outside influence” narrowly.

\section{Shortcuts}

The Rule also bars juror testimony or statements that tend to show improper decisional shortcuts that juries sometimes take during deliberations. Thus the Rule applies to proof that the

guilty by reason of insanity would be "less effective" in removing from society), cert. denied, 488 U.S. 1013.

15. United States v. Falsia, 724 F.2d 1339, 1343 (9th Cir. 1983) (jurors affected by co-offender’s absence from trial).

16. Carson v. Polley, 689 F.2d 562, 579-582 (5th Cir. 1982) (foreman's letter to judge said plaintiff had no case, legal fees were paid from public fund, and lawyers were making money while disserving plaintiff); Martinez v. Food City, Inc., 658 F.2d 369, 372-373 (5th Cir. 1981) (in suit for overtime wages, juror said defendant should be "taught a lesson”).

17. United States v. Bowling, 900 F.2d 926, 935 (6th Cir. 1990) (“negative and inappropriate comments” by juror), cert. denied, 498 U.S. 837; United States v. Chiantese, 582 F.2d 974, 978-979 (5th Cir. 1978) (juror remark that defense cross was stupid and counsel was a "pain”).

18. Tanner v. United States, 483 U.S. 107 (1987) (regardless how “severe their effect and improper their use,” drugs or alcohol voluntarily consumed by juror are no more an outside influence "than a virus, poorly prepared food, or a lack of sleep”) (jurors drank beer, mixed drinks, and wine, and indulged in marijuana and cocaine).

19. See further discussion in $\S 6.14$, infra. 
jury agreed on a time limit for deliberations, ${ }^{20}$ or that one or more jurors had prior knowledge about a party, ${ }^{21}$ or entertained preconceptions about the case, ${ }^{22}$ or began deliberations early before being formally charged or sent out to do so. ${ }^{23}$ The Rule also applies to proof that one or more jurors compromised principles out of concern over personal matters in order to end deliberations quickly, ${ }^{24}$ or engaged in vote trading, giving ground on one issue or party in exchange for concessions by other jurors on other issues or parties..$^{25}$ The Rule applies as well to evidence that one or more jurors agreed to abide the vote of a majority, or a number less than that necessary for a proper verdict, ${ }^{26}$ or arrived at the sum to be awarded by adding the amounts each juror thought appropriate and dividing by the number of jurors (the classic "quotient verdict"). ${ }^{27}$ And the Rule bars juror testimony or statements indicating that one or more jurors gave in to pressure from other jurors by casting votes against better judgment or conscience without being truly persuaded, ${ }^{28}$ or gave in to pressures from the court in setting long hours for deliberations ${ }^{29}$ or urging the jury to

20. Capella v. Baumgartner, 59 F.R.D. 312, 314-315 (S.D. Fla. 1973) (jury agreed to give in by certain time or hour in reaching verdict).

21. United States v. Eagle, 539 F.2d 1166, 1170 (8th Cir. 1976) (juror realized during trial that defendant was wanted for shooting FBI agents in unrelated incident) (did not relay point to others), cert. denied, 429 U.S. 1110. But prior knowledge about the case can be proved as extrarecord information. See §6.12, infra.

22. Brofford v. Marshall, 751 F.2d 845, 852-853 (6th Cir. 1985), cert. denied, 474 U.S. 872.

23. United States v. Leung, 796 F.3d 1032, 1036-1037 (9th Cir. 2015) (cannot show that jurors "made up their minds prematurely and discussed the evidence before the start of deliberations").

24. United States v. Fozo, 904 F.2d 1166, 1171 (7th Cir. 1990) (impending Christmas holiday may have caused jury to rush deliberations); McElroy v. Firestone Tire \& Rubber Co., 894 F.2d 1504, 1510-1511 \& n.11 (11th Cir. 1990) (juror seen "crying and expressing a desire to be with her family").

25. Stein v. New York, 346 U.S. 156 (1953) (jurors exchanged convictions on one issue in return for concessions on another issue); Hyde \& Schneider v. United States, 225 U.S. 347 (1912) (trading conviction of one for acquittal of another); United States v. Kennedy, 714 F.3d 951, 960 (6th Cir. 2013) (cannot interview jurors to pursue theory that they reached compromise verdict).

26. United States v. Marrero, 904 F.2d 251, 261 (5th Cir. 1990) (juror said majority rule controlled), cert. denied, 498 U.S. 1000; United States v. Howard, 507 F.2d 559, 561 n.3 (8th Cir. 1974) (foreman said jury was not unanimous).

27. See Stein v. New York, 346 U.S. 156 (1953); McDonald v. Pless, 238 U.S. 264 (1915).

28. United States v. Briggs, 291 F.3d 958, 963 (7th Cir. 2002) (juror said she had been "intimidated" by others into voting in favor of guilt); United States v. Tallman, 951 F.2d 164, 166-167 (8th Cir. 1991) (reported "harassment and insults" in jury room).

29. United States v. Marques, 600 F.2d 742, 746-748 (9th Cir. 1979) (reports of compromise because court kept jury 
reach a verdict, ${ }^{30}$ or reminding it that unanimity is required. ${ }^{31}$

\section{Interpretation of verdict}

Nor can jury testimony or statements be admitted to interpret the verdict or prove that mistakes were made in reaching it. The Rule bars proof in the form of statements explaining or qualifying the verdict after it was taken, ${ }^{32}$ or showing that one or more jurors did not agree with or believe in the verdict, ${ }^{33}$ or erred in calculating the award, ${ }^{34}$ or miscast his vote in a tenor opposite to what he intended ${ }^{35}$ although an error in entering the verdict onto the form may be proved, ${ }^{36}$ or that the verdict was the result of mistake ${ }^{37}$ or prejudice. ${ }^{38}$ And the Rule bars proof that one or more jurors was inattentive during trial or deliberations, sleeping or thinking about other matters, ${ }^{39}$ or even

deliberating until 11 P.M. Friday and 10 P.M. the following Monday), cert. denied, 444 U.S. 858.

30. United States v. Vincent, 648 F.2d 1046, 1049-1050 (5th Cir. 1981) (reports of pressure and weeping after court gave Allen charge).

31. Watson v. Alabama, 841 F.2d 1074, 1075-1076 (11th Cir. 1988) (reporting “distraught and upset” jurors; all twelve raised hands "but two women jurors were shaking their heads"; refusing to consider juror testimony on effect of instruction requiring unanimity when jury polled), cert. denied, 488 U.S. 864.

32. Sims’ Crane Serv., Inc. v. Ideal Steel Prod., Inc., 800 F.2d 1553, 1555-1557 (11th Cir. 1986); Michaels v. Michaels, 767 F.2d 1185, 1204-1205 (7th Cir. 1985), cert. denied, 474 U.S. 1057.

33. Hall v. Levine, 104 P.2d 222 (Colo. 2005) (that verdict was not unanimous, where all signed verdict form and jury was polled); United States v. Miller, 806 F.2d 223, 225 (10th Cir. 1986) (juror having second thoughts, unsure of guilt).

34. Stewart v. Rice, 47 P.3d 316, 326 (Colo. 2002) (jurors may not have intended to award damages for physical impairment or may have forgotten to make award for physical impairment or may have confused interrogatory as asking for total award or may have disregarded its plain language).

35. York Chrysler-Plymouth, Inc. v. Chrysler Credit Corp., 447 F.2d 786, 794 (5th Cir. 1971) (foreman’s affidavit said jury intended verdict to run against dealership as well as individuals).

36. See the discussion in $\S 6.14$, infra.

37. United States v. Sjeklocha, 843 F.2d 485, 488 (11th Cir. 1988); United States v. Schwartz, 787 F.2d 257, 261

(7th Cir. 1986).

38. Poches v. J. J. Newberry Co., 549 F.2d 1166, 1169 (8th Cir. 1977) (cannot impeach by showing prejudiced verdict).

39. See Government of Virgin Islands v. Nicholas, 759 F.2d 1073, 1079-1081 (3d Cir. 1985) (juror hearing 
drugged or intoxicated. ${ }^{40}$

\section{Chance and quotient verdicts}

In three difficult areas the mandate of FRE 606(b) remains uncertain. One is chance verdicts; another is verdicts tainted by racial bias; the third is violent intimidation in the jury room. Probably the Rule bars juror testimony or statements that a verdict was reached by chance or lot, although some states made special provision allowing such proof. ${ }^{41}$ Reaching a verdict by chance or lot seems to be a matter occurring during deliberations (so the Rule applies), and the exceptions do not seem to apply (flipping a coin is not extraneous prejudicial information or outside influence in the most obvious sense of those terms). But verdicts resting on chance or lot do more violence to the ideal of a consensus decision reflecting the wisdom and attitude of the community than does a quotient verdict: The latter contains elements of thought and may approximate what the bargaining process would otherwise produce, but decisions by chance or lot are essentially the negation of thought and give-and-take. Arguably a coin flip or its equivalent is outside influence: It introduces a decisive force that is outside the evidence and mental processes of the jury. However, the Court's insistence in Tanner that drug consumption is not outside influence makes this argument more difficult.

\section{Racial, gender bias}

Verdicts tainted by serious prejudice along racial or ethnic lines proved problematic for many years. On the one hand, FRE 606(b) appears to bar proof of such prejudice (it would disclose the "effect” of something on jury decisionmaking and a juror's “mental processes"), but on the other hand, verdicts tainted in such ways would appear to violate constitutional principles. ${ }^{42}$ In its 2017 decision in the Peña-Rodriguez case, the Supreme Court held that indeed the Sixth Amendment jury trial right in criminal cases, in state and federal courts alike, entitles a convicted defendant to show that a jury "relied on racial stereotypes or animus to convict," and Rule 606(b) must give

impairment).

40. Tanner v. United States, 483 U.S. 107 (1987) (alcohol and drug abuse).

41. See Senate Hearings, at 50 (1974) (rule insulates verdicts from attack on ground that they were reached by chance). See also the counterparts in Idaho, Montana, and North Dakota (all allowing proof that verdict was reached by "chance"). See also Tennessee Rule 606 (allowing proof that jurors "agreed in advance to be bound by a quotient or gambling verdict”).

42. See United States v. Villar, 586 F.3d 76, 82-87 (1st Cir. 2009) (FRE 606(b) "precludes any inquiry into the validity of the verdict based on juror testimony regarding racial or ethnic comments" during deliberations) (but due process rights and Sixth Amendment require court, when faced with ethnically biased statements by a juror during deliberations, to conduct inquiry and set verdict aside if there is "a substantial probability that any such comments made a difference in the outcome”); Williams v. Price, 343 F.3d 223, 237-238 (3d Cir. 2003) (noting argument that showing racial bias should be allowed; refusing to recognize such exception does not violate Constitution; remanding to determine whether juror lied about prejudice on voir dire) (quoting authors of this Treatise). 
way to the extent necessary to permit such a showing. The Court was careful to add that a mere "offhand comment" indicating bias or hostility does not "justify setting aside the no-impeachment bar" and that further inquiry is justified only on "a showing that one or more jurors made statements exhibiting overt racial bias that cast serious doubt on the fairness and impartiality" of the deliberations, and that the evidence must "tend to show that racial animus was a significant motivating factor" in a juror's vote to convict. One post-Peña-Rodriguez decision declined to reverse where one member of the jury told another that it was "strange that the two colored women are the only two that can't see” the guilt of the defendants, and that the two jurors just thought they "owed something" to their "black brothers." The reviewing court thought these comments were not a "clear statement" proving that race was a "significant motivating factor" in the verdict. ${ }^{43}$

In the Peña-Rodriguez case, the Supreme Court acknowledged that its decisions in 1987 in the Tanner case and in 2014 in the Warger case had rejected claims of constitutional entitlement to challenge jury verdicts (as noted above, Tanner involved juror intoxication in a criminal trial; the Warger case ${ }^{44}$. involved failure to disclose pro-defense bias in a civil matter), but Peña-Rodriguez concluded that racial bias is different, quoting an earlier case labeling such bias as "odious in all aspects" and "especially pernicious in the administration of justice." 45

It remains to be seen whether the Sixth Amendment jury trial right articulated in PeñaRodriguez will really be limited to proof of racial stereotypes or animus in criminal cases. Juror attitudes on matters like gender, sexual identity or preference, religion, or age could also lead to plausible challenges to verdicts, and would also be “odious” and “pernicious.” In Peña-Rodriguez, the Court referred to decisions outlawing peremptory challenges to jurors based on gender (as well as race), which suggests both that privileging race-based challenges is hard to rationalize, and also that the Court thought that race and gender really do harbor distinctly troublesome forms of bias or prejudice. The cases dealing with bias in peremptory challenges rested on Equal Protection rather than jury trial entitlement, and the focal point was the rule allowing peremptories, so those cases are clearly different from challenges to a verdict as such. The basis of Peña-Rodriguez was the Sixth Amendment, which guarantees a jury trial right in both state and federal court, but only in criminal cases. There is no corresponding federal guarantee in civil cases litigated in state court (although the Seventh Amendment guarantees a jury trial entitlement in civil cases in federal court). Thus Peña-Rodriguez does not provide ground for challenging civil jury verdicts, although Equal Protection arguments could reach civil verdicts, whether in state court or in federal court.

\section{Physical intimidation}

Probably the Rule bars proof of physical intimidation or violence by one or more jurors against others during deliberations, but some state provisions make room for challenges raising this

43. United States v. Robinson, 872 F.3d 760, 770-771 (6th Cir. 2017) (dissenting judge argues that proof of the juror's comment warranted further inquiry into the verdict).

44. Warger v. Shauers, 135 S. Ct. 521 (2014) (discussed in §6.14, infra).

45. Peña-Rodriguez v. Colorado, 137 S. Ct. 855, 868-870 (2017) (quoting Rose v. Mitchell, 443 U.S. 545, 555

(1979)). 
point ${ }^{46}$ It is easy to see why allowing this kind of challenge would prove troublesome: The system would likely be badly hobbled if charges of overbearing or argumentative behavior could upset a verdict. On the other hand, barring all challenges along these lines is troublesome too: The system can hardly tolerate verdicts following episodes that include fistfights or kicking or throwing chairs to coerce a particular verdict, and some have suggested that the Rule should be amended to allow proof along these lines. ${ }^{47}$

\section{Incompetent jurors}

In a few reported decisions, it came to light after a verdict that a juror appeared to be mentally incompetent in some sense that was troublesome to other jurors-out of touch with reality and unable to participate constructively in deliberations. The Supreme Court has held that the jury trial right includes the right to be tried by jurors who are mentally competent, ${ }^{48}$ and a few courts have indicated that a defendant in a criminal case may challenge a verdict returned by a jury with a mentally incompetent member. ${ }^{49}$ Other cases have rejected such challenges ${ }^{50}$ Like challenges based on racial bias or stereotyping or violence in the jury room, a challenge based on mental competency of a juror seems too serious to ignore altogether, and some room may have to be found to entertain such challenges too, even though the Rule does not seem to permit them.

46. United States v. McGhee, 532 F.3d 733, 740-741 (8th Cir. 2008) (not ordering hearing when jurors alleged intimidation by others; FRE 606(b) bars testimony as to "how the jury reached its verdict" and jurors "were not competent to testify about alleged intimidation”); State v. Kim, 81 P.3d 1200, 1206 (Haw. 2003) (juror “intimidated and harassed" another by saying "What the fuck are we doing this for? I want to know who voted for the Manslaughter. I want to know who the fuck said manslaughter?”) (affirming murder conviction). But see Minnesota Rule 606(b) (allowing proof of "threats of violence or violent acts" against jurors, "from whatever source”); Ohio Rule 606(b) (authorizing juror testimony on "any threat, any bribe, any attempted threat or bribe, or any improprieties of any officer of the court”).

47. Carlson \& Sumberg, Attacking Jury Verdicts: Paradigms for Rule Revision, 1977 Ariz. State L.J. 247, 274 (should allow affidavit that "threat or act of violence was brought to bear" on juror to reach verdict). And see Robinson \& Reed, A Review of the Proposed Michigan Rules of Evidence, 56 Mich. St. B.J. 21, 29 (1977).

48. Tanner v. United States, 483 U.S. 107, 125 (1987) (conclusive proof of juror incompetence may be admissible); Peters v. Kiff, 407 U.S. 493, 501 (1972) (criminal conviction by jury with insane member may violate due process) (plurality opinion); Jordan v. Massachusetts, 225 U.S. 167, 176 (1912) (due process requires mentally competent jurors).

49. See, e.g., Sullivan v. Fogg, 613 F.2d 465 (2d Cir. 1980) (granting relief from murder conviction where juror told DA that he had been harassed by voices during trial).

50. See, e.g., United States v. Perry, 643 F.2d 38, 51 (2d Cir. 1981) (rejecting claim that mental instability of juror required conviction to be set aside). 